\title{
Changes in pinyon-juniper woodlands in western Utah's Pine Valley between 1933-1989
}

\author{
TERENCE P. YORKS, NEIL E. WEST, AND KATHLEEN M. CAPELS
}

\begin{abstract}
Authors are former postdoctoral research associate, professor, and former volunteer associate, respectively, Department of Range Science and the Ecology Center. Utah State University. Logan. Ut. 84322-5230
\end{abstract}

\begin{abstract}
Changes in woodland vegetation integrate the consequences of livestock grazing intensity, the alteration of fire regimes, and possible climate alteration, as well as other factors. Quantitative measurements of these changes, if taken over sufficient intervals, can allow evaluation of conservation management strategies. In 1933, vegetation along a 37- $\mathrm{km}$ transect in southern Pine Valley, Utah was described from circular $19-\mathrm{m}^{2}$ plots located every $42 \mathrm{~m}$. The major intermediate management treatment has been reduction of grazing pressure by introduced animals, although a fraction of the area was chained and burned in 1977 . During a period climatically and phenologically similar to the original study, we re-examined representative segments of this transect by a more detailed updating of the original "square-foot-density" method. Significantly greater shrub and perennial grass covers (more than threefold increases) were found in 1989 , even where overall dominance is still by pinyon-juniper [Pinus monophylla (Torrey \& Fremont) and Juniperus osteosperma (Torrey) Little]. This change is more obvious on steeper slopes away from roads and water, where both human and livestock disturbances would be expected to be minimized. Except in the chained portion, the observed shifts in dominance/diversity are contrary to widely accepted expectations.
\end{abstract}

Key words: Pinus monophylla, Juniperus osteosperma, pinyon-juniper, livestock grazing, canopy cover, vegetation change

One of the more pressing issues in rangeland management is whether or not ecosystems can recover some of their original diversity and species composition after substantial, and/or lengthy, humaninduced disturbances. Recovery questions are important because such a large percentage of this planet's land surface has been so intensively disarranged. One special focus for concern is the probability that wherever rainfall is low and soils are thin, threshold effects can confine vegetation within what is a clearly different and simpler ecosystem type (Laycock 1991). Alternatively, the question becomes, if positive change might be effected, over what time frame will it occur, and by what paths?

Thanks are due to Dr. Frederick Wagner as a prime mover in our financial support; to the U.S. Environmental Protection Agency for that primary funding; to Utah State University for essential practical support services; to the USDI BLM (especially to Sheridan Hansen) for their helpfulness in reconstructing management in Pine Valley over time, as well as for the use of their many detailed maps; and to the USDA Forest Service Shrub Sciences Laboratory in Provo, Ut.. for allowing us access to the original 1933 data. We are grateful to Dr. Steven Sparks for an intensive preliminary literature search; to Susan Durham for comments on statistical validity; to Joseph Pechanec, the 1933 study's field crew leader, for his reminiscences; and to Ralph Holmgren, long-time scientist at the Desert Experimental Range, for his background commentary on the history of Pine Valley.

Manuscript accepted 26 Mar. 1994.
A vital subset of this issue occurs where domestic livestock have been the most active disturbance vector. A pressing social and environmental question is whether or not a reduction in (rather than elimination of) grazing pressure, without other action, can be sufficient to allow recovery in actual practice. Critics point to personal perceptions of livestock destructiveness, and continuing government reports of vast tracts that remain in "fair" or worse condition, despite stocking rate reductions (e.g., Wald and Alberswerth 1989). Long-term quantitative data, with which to examine this issue in a more fully scientific fashion, have been singularly lacking (Box 1990). We recognize, but will not be entering into, the parallel debate about possible special values of intermediate successional stages to either livestock or wildlife, although the data presented herein should be of value to them, as well.

Pinyon pine [Pinus monophylla (Torrey \& Fremont)] and Utah juniper [Juniperus osteosperma (Torrey) Little] woodlands are of particular interest within the above considerations because of their large area of dominance in the southwestern United States (Evans 1988), and because their understory productivity has been expected to continue to decline after being extensively disturbed (West 1984). The present pinyon-juniper woodlands in the southwestern U.S. may be far different in their vegetation structure from what occurred there before Europeans settled in their area. Examination of relict areas, tree age class structures, fire scars, and historical documents leads to a belief that much of the pinyon-juniper woodland was once much more open and "savannah like" (West 1988).

When livestock were introduced, they concentrated on the perennial grasses that were palatable to them. Where grazing was excessive, fires could no longer perform their previously-established thinning functions since the grasses, which had provided sufficiently well-distributed, fine fuels, were not consistently available. Fire activity may also have been reduced by passive constraints (e.g., roads) and/or active suppression efforts. When unrestrained either by fire or by a full complement of plant competition, the trees, with their resistance to herbivory and decay and greater physiological efficiencies, thicken their canopy cover. These factors correlate, in most previous studies, with a further decline in understory productivity as the trees mature (West 1984).

Western Utah's pinyon-juniper woodlands were among those heavily impacted by domestic livestock during the period following European immigrant settlement in the mid-1800's. Stocking rates tended to remain at destructive levels until soil erosion sufficiently troubled human settlements downstream, or the animals simply could no longer find enough to eat at their originally introduced densities (Cottam 1961).

Concern remains that expanses now dominated by these tree species have low diversities of plants (West et al. 1979) and animals (Balda 
and Masters 1980). Consequently, there have been calls for management action to diversify the structure of these woodland belts (West 1984). This has been seen to be no simple problem. Koniak and Everett (1982) argue that even if openings are artificially made, very few native plants recover, apparently because seed banks and seed sources have been lost.

As a basis from which to address these questions further, an unusually detailed and extensive long-term baseline study of vegetation status was carried out in 1933 in western Utah's Pine Valley, at the time when livestock reductions actually began (Stewart et al. 1940). A recent restudy, after 55 years, of the desert shrubland portion of that 37 $\mathrm{km}$ transect has been reported elsewhere (Yorks et al. 1992). The purpose was to determine whether or not change in vegetation status has followed the reductions in grazing pressure that have resulted from active implementation of the Taylor Grazing Act. Examination of the woodland section uncovered sufficiently different issues, within the same overall goal, to be reported upon separately. Nearly all of the climatic description, materials, and methods sections of the companion piece (Yorks et al. 1992) remain applicable, however. For that reason, these sections are abridged herein. The question of single-year studies, and precipitation impacts, were also discussed in more extensive detail in the previous paper, as are other limitations on data accuracy and internal calculations.

\section{Study Site}

This Pine Valley is found in Millard and Beaver Counties, in southwestern Utah. It lies between $38^{\circ}$ and $39^{\circ} \mathrm{N}$ Lat. and $113^{\circ}$ and $114^{\circ} \mathrm{W}$ Long. The valley is defined by north-to-south mountain ridges, which are characteristic of the Great Basin area in general. The Wah Wah and Needle Ranges border it on the east and west, respectively. Pine Valley's minimum elevation of $1,547 \mathrm{~m}$ is at the salt pan at the valley's north end, next to the Desert Experimental Range of the USDA's Forest Service. The valley's high point of $2,984 \mathrm{~m}$ is at Indian Peak, which was part of an Indian reservation in 1933, and is now included in a state game management reserve.

The pinyon-juniper woodland belt on the Needle Range begins at about $1,900 \mathrm{~m}$ elevation and continues until about 2,200 m. The 1933 study transect included $6 \mathrm{~km}$ within this belt to the northcast of Indian Peak. Between the sections of the transect that were restudied, a 1-km swath had been chained to break off or uproot standing trees, burned, and seeded with a mixture of introduced and native perennial grasses in 1977 . Slopes average $4 \%$ along the transect line below, and within, the chained area. These have a generally northeast aspect. Above the chaining, slopes average $12 \%$, with a generally southeast aspect. Erosional washes cross the transect at approximately 250- to 500-m intervals. These deepen from a gradual slope with $<1-\mathrm{m}$ depth to as much as $20 \mathrm{~m}$ deep with nearly vertical walls as overall slopes increase. Soils are generally shallow, have upland loam to upland shallow loam range site classifications (unpublished data, Beaver River Resource Area, Cedar City District, BLM, USDI), and contain occasional outcroppings of bare rock.

In the general study area, both rainfall and temperature may be expected to vary greatly with elevation, as well as within, and among, years. Precipitation has been measured in Pine Valley itself for an extended period only at a lower elevation site, on the Desert Experimental Range. There, the October-to-September "crop year" (Sneva and Britton 1983) average was $160 \mathrm{~mm}$ over the period 1950 to 1983 , with about $100 \mathrm{~mm}$ falling in the cool season (October to June). Spatial variation for warm-season precipitation within the valley is likely to be higher, because it results from convectional storms (Stewart et al. 1940). Pan evaporation rates are several times the amount of incident rainfall. Overall temperature extremes have been from plus to minus $40^{\circ} \mathrm{C}$; there is typically a $20^{\circ} \mathrm{C}$ diumal variation
(Clary and Holmgren 1982). Winds tend to be consistently strong.

Within these overall considerations, this repeat study was carried out in similar climatic and phenological situations to the original, i.e., in the same time period of a holter-and-drier-than-normal year, and after 3 years of relative drought. This should minimize the probability that either short-term climate or phase of growth would be a primary cause of plant cover differences within this study.

Historically, a lack of permanent water kept domestic livestock from grazing Pine Valley until about 1890 , when water well development attracted the first cattle. They were followed in about 10 years by the introduction of sheep, at high intensities of year-round use (Murdoch and Welsh 1971). "Seriously destructive" was the phrase of Stewart et al. (1940) for early grazing practices. Consequent erosion was moderate to severe, and in places exceeded $15 \mathrm{~cm}$, with some dune development (Murdoch and Welsh 1971). Substantial, but undocumented, reductions in stocking rates occurred in response to inadequate forage in the 1930's (S. Hansen and W. DiAge, Bureau of Land Management, Cedar City, Utah, personal communication, 1989). According to this same source, a further $33 \%$ reduction occurred as a part of 1950's adjudication agreements. Concomitantly, a free-ranging herd of feral horses was eliminated from the general area in the 1940's (V. Wood, permittee, personal communication, 1991). In 1958, the average Pine Valley stocking rate was estimated to be 3 ha/AUM (Murdoch and Welsh 1971). Although grazing records (unpublished data, Beaver River Resource Area, Cedar City District, BLM, USDI) are incomplete and internally inconsistent, there appears to have been little or no grazing by legally permitted numbers of sheep during the years 1967 to 1977 within the pinyon-juniper woodlands. No fencing crosses the pinyon-juniper belt studied here.

\section{Methods}

The in-the-field location for the 1933 study (Stewart et al. 1940, augmented by the original data sheets) was repeated by visual sighting of the geographically-obvious end points of the transect line, supplemented as necessary by a hand-held compass. The distance between regularly-spaced plot centers along the line was established with a steel tape, since even spacing was the method used to provide an unbiased sampling. Specific plot numbers were established by relationships to intermediate topographical details (such as washes or roads) on the original 1933 contour maps, or of particular plots noted thereon to 1913 county survey posts on our contemporary maps. Sample sizes were chosen to be large enough to obviate, in as far as practically possible, the inevitable inaccuracy in our attempts to precisely relocate individual plots.

Fullowing Stewart and Hutchings (1936) and Stewart et al. (1940), we employed a central stake as a pivot on each plot, and used a nonstretching rope with a $50-\mathrm{cm}$ section of steel rod at its other end to mark a circle enclosing $19 \mathrm{~m}^{2}\left(200 \mathrm{ft}^{2}\right)$ on the ground. The "squarefoot-density" method of the 1933 study depended upon estimating cover (to the nearest $0.023 \mathrm{~m}^{2}$, i.e., $0.25 \mathrm{ft}^{2}$ ) for each plant species. That cover, in turn, was defined as the area where the ground "could not be seen by an observer standing directly over it" (Stewart et al. 1940). Any individual plant that did not have such complete coverage (like most in practice) was to be visually compressed until it did so.

In 1989 , we chose to refine the 1933 visual summary estimates for each species. We manually compressed the plant (if necessary to achieve essentially complete shadow coverage), and measured the diameter of the top of each plant's canopy with a meter stick, and directly recorded it in field notebooks, to allow more detailed subsequent analyses. With the assistance of a computer to calculate the areas from these diameter records, no more time was required for this method than to follow the older practice of simple estimates. Numbers of dead, living, and seedling shrubs or trees are direct counts of these 
plants that had the center of their basal stem, or stem cluster, within the circle.

Ten percent of the 52 plots read in 1989 were estimated a second time by the same observer, and additionally by 2 different observers, with sufficient time between such readings to dissipate mental carryover. Density (i.e., the absolute number of plants per unit area) varied at most by $10 \%$, and was typically less than $5 \%$, both for a single observer's repetition and between observers. Replicate readings of species cover also fell within this same pattern, when made by a single observer.

However, cover estimates for the same plot, when made by different observers, varied much more widely. This is as might be expected from what seems to be an unavoidably subjective compression of plants to derive continuous shadows (West and Hatton 1990). This variation in apparent cover reached as much as $50 \%$ for some more openly-structured species.

Accordingly, we have adopted the convention of Wheeler et al. (1989) for rounding in all reported data, or have been even more conservative in its expressed accuracy. "Significant" is defined for use in the following text as specified by Lewis (1984) for use of Student's T test, where $P<0.05$ that the difference in question would have resulted from random chance. "Highly significant" applies similarly to $P<$ 0.01 .

Nomenclature herein is according to Goodrich (1986). Growth form assignments follow those of the USDA-SCS (Anon. 1988).

\section{Results}

Overall live cover from vascular plants was not significantly different in 1989 (with an arithmetic mean of $24 \% \pm 2 \%$ standard error for that mean) from that for $1933(21 \pm 4 \%)$. Nevertheless, the lower sample variability in 1989 may be of interest as an indicator for constancy of cover.

Examination of the separate contributions among the several growth forms that comprise the live plant cover (Fig. 1) points to a shift towards understory that is even greater than that reported in Yorks et al. (1992) for the other major vegetation types. Increases for shrubs, half-shrubs, and perennial grasses are all highly significant (Table 1). In other words, this area may be changing from cover concentrated among trees to a mixture with more shrubs (primarily sagebrush) and a variety of grasses.

Another possible connotation to be gleaned from Figure 1 is that the overall canopy cover may have reached an upper limit, which is approximately $20 \%$ for the sum of all growth forms. This effect is interesting, because it appears to be in sharp contrast to the significant increase in the total amount of cover found for shrub-dominated plots in the related paper (Yorks et al. 1992). Instead, the vegetation differences between 1933 and 1989 indicate a possible reapportionment of a continuing $20 \%$ overall cover among the various species on pinyonjuniper plots.

In a related occurrence, there is now a more gently sloped log-linear decline in dominance/diversity relationships (Fig. 2), instead of an initial, exponential drop-off. Many more species were playing a greater relative role in the overall canopy cover in 1989 than in 1933. This is especially true in ranks 6 through 14, each of which is nearly an order of magnitude greater in its relative cover, and significantly different, than it was in 1933.

The sum of absolute tree cover did not differ significantly after 55 years (Fig. 1, restricted to data from unchained plots). Among the trees, the primary effect of time on cover is a significant shift from the dominance of juniper to pinyon (Table 1). This same result was clearly seen in a chronosequence study at a single site within Pine Valley (Tausch and West 1989).

More particularly, if 1933 data are disaggregated to the individual

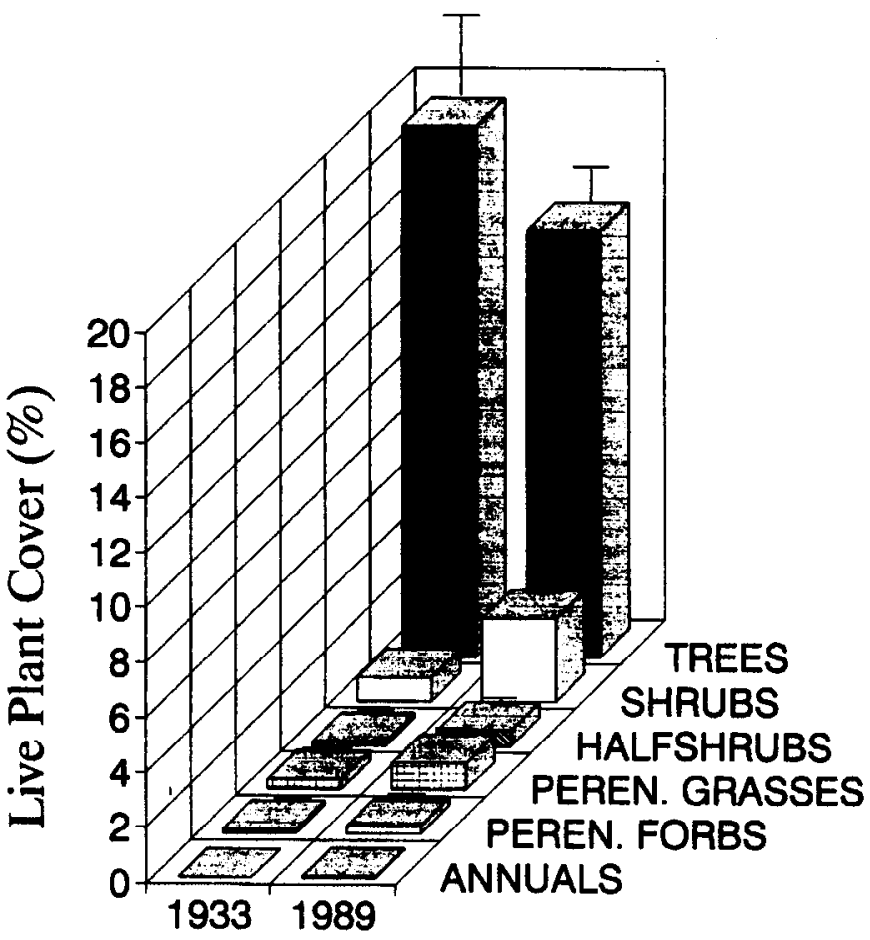

Fig. 1. Absolute cover among growth forms on unseeded plots in pinyonjuniper woodlands in Pine Valley, Ut., 1933 and 1989.

plot level (Fig. 3), and the chained area is set aside, 2 specific locations appear to have had an atypically high tree cover. Recalculating the aggregate sums without these uutliers underlines the apparent constancy of overall tree cover over time. That data manipulation does not change the significant juniper-to-pinyon species shift, however.

Figure 4 depicts the distribution of perennial grass cover by plot number along the transect. This figure presents results for all mea-

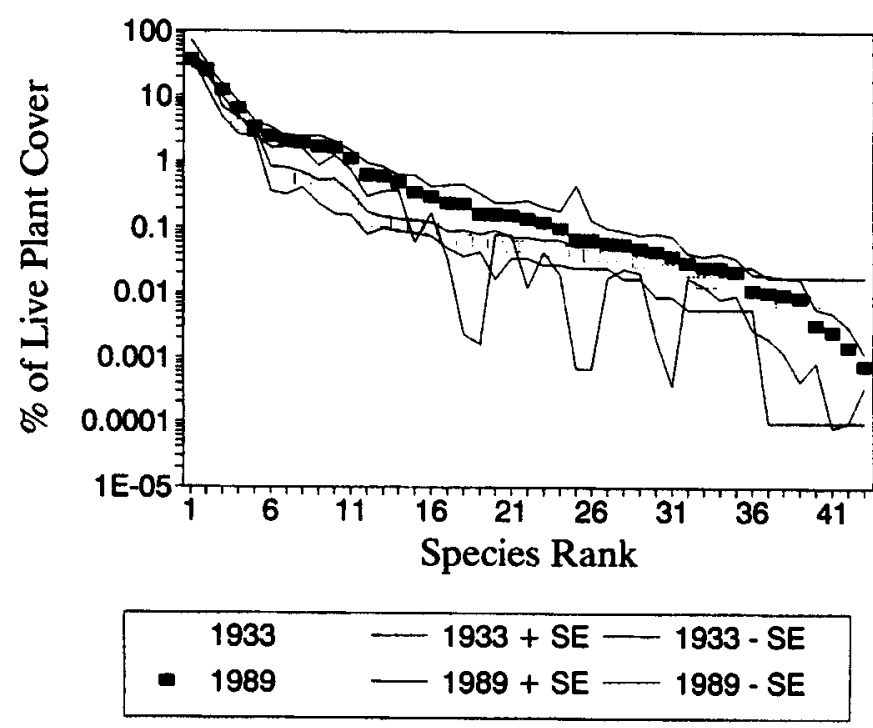

Fig. 2. Dominance/diversity among species on unseeded plots in pinyonjuniper woodlands in Pine Valley, Ut., 1933 and 1989. 
Table 1: Plant species (mean live plant cover, \pm standard error of that mean), on unseeded plots in pinyon-juniper woodlands of Pine Valley, Ut., 1933 and 1989.

\begin{tabular}{l}
\hline Growth form/species: \\
\hline All Trees: \\
Juniperus osteosperma \\
Juniperus osteosperma \\
Pinus monophylla' \\
Pinus monophylla \\
Populus spp.' \\
Populus spp. ${ }^{2}$
\end{tabular}

\section{All Shrubs:}

Artemisia nova

Purshia tridentata

Chrysothamnus viscidiflorus

Haplopappus nanus

Opuntia spp.

Ephedra viridis

Artemisia tridentato

Echinocereus spp.

Grayia spinosa

Ephedra nevadensis

Symphoricarpos spp.

Chrysothamnus spp.

All Half shrubs:

Gutierrezia sarothrae

Eriogonum microthecum

Artemisia ludoviciana

All Perennial grasses:

Bouteloua gracilis

Poa spp.

Aristida spp.

Sitanion hystrix

Oryzopsis hymenoides

Agropyron spicatum

Stipa comata

All Perennial forbs

Senecio spp.

Eriogonum spp.

Cryptantha spp.

Astragalus spp.

Arenaria spp.

Caulanthus spp.

Penstemon spp.

Euphorbia fendleri

Sphaeralcea grossulariaefolia

Erigeron engelmanni

"Red weed"

Chaenactis douglasii

Cirsium spp.

Heuchera rubescens

Oenothera spp.

Machaeranthera grindelioides

Petradoria pumila

Arabis spp.

Gilia spp.

Thelypodium spp

1933

1989

$19 \pm$

$12 \pm 3$

$1.2 \pm 0.2$

$4 \pm 2$

$0.7 \pm 0.2$

0

0

$0.8 \pm 0.1$

$0.6 \pm 0.1$

$0.07 \pm 0.04$

$0.07 \pm 0.04$

$0.05 \pm 0.02$

$0.022+0.005$

$0.008 \pm 0.003$

$0.003+0.002$

$0.003 \pm 0.002$

$0.003 \pm 0.002$

$0.002 \pm 0.002$

0

0

$0.13 \pm 0.05$

$0.12+.05$

$0.011 \pm 0.008$

$0.006 \pm 0.003$

$\begin{array}{ll}0.34 \pm 0.07 & 1.1 \pm 0.2 * * \\ 0.12 \pm 0.05 & 0.4 \pm 0.1 * \\ 0.11 \pm 0.03 & 0.15 \pm 0.06 \\ 0.03 \pm 0.1 & 0.04 \pm 0.02 \\ 0.049 \pm 0.005 & 0.29 \pm 0.05 * * \\ 0.021 \pm 0.005 & 0.12 \pm 0.03 * * \\ 0 & 0.006 \pm 0.004 \\ 0 & 0.002 \pm 0.002\end{array}$

$0.13 \pm 0.01$

$0.014 \pm 0.004$

$0.027 \pm 0.005$

$0.016 \pm 0.003$

$0.012 \pm 0.004$

$0.011 \pm 0.004$

$0.011 \pm 0.004$

$0.010 \pm 0.004$

$0.006 \pm 0.002$

$0.006 \pm 0.003$

$0.005 \pm 0.003$

$0.005 \pm 0.003$

$0.002 \pm 0.002$

$0.002 \pm 0.002$

$0.002 \pm 0.002$

$0.002 \pm 0.002$

0

0

0

0

All Annuals:

Bromus tectorum

Halogeton glomeratus

\begin{tabular}{ll}
0 & $0.012 \pm 0.007$ \\
0 & $0.012 \pm 0.007$ \\
0 & $0.0001 \pm 0.0001$ \\
\hline
\end{tabular}

*.** Significant change at the 0.05 and 0.01 levels, respectively

'Overstory

${ }^{2}$ Understory: basal area plus seedlings

sured plots, including those within the swath that had been chained, burned, and seeded with a varied mixture of perennial grasses (as does Fig. 3). Other portions of the area that had been chained were not re-

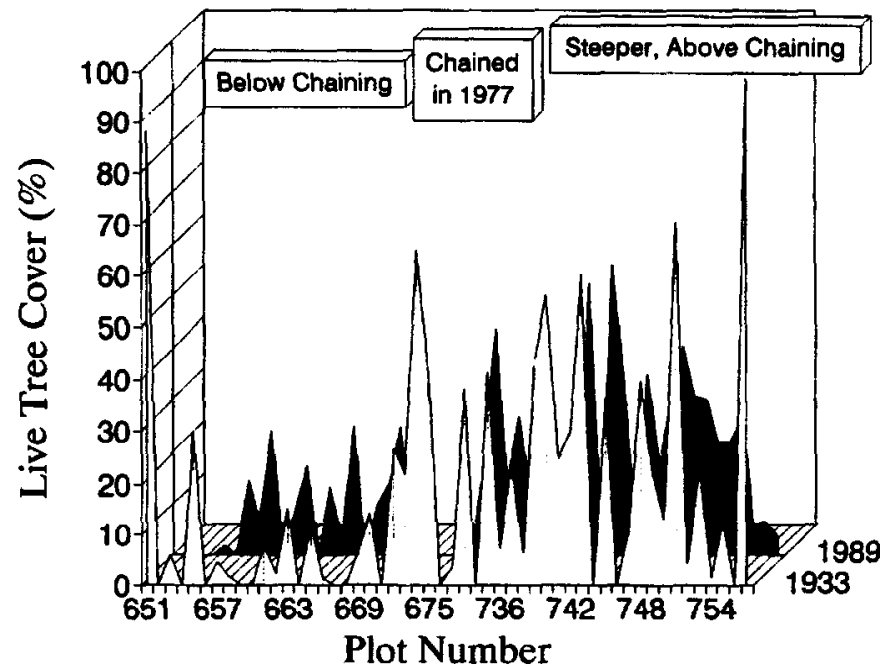

Fig. 3. Spatial variation in total live plant cover by trees, for all plots, from northeast, lowest elevation (left) to southwest, highest elevation (right) along the pinyon-juniper woodland transect, Pine Valley, Ut., 1933 and 1989.

sampled, since their composition had been so heavily manipulated. (This accounts for the break in the plot numbering in Figs. 3 and 4). Nevertheless, the area of tree removal which was measured (plots 671 to 676) should make obvious the general results of the chaining and seeding efforts.

Interestingly, among the unseeded plots, those at higher elevation (and topographically steeper) had the most significant increase in grass cover from 1933 to 1989 . This is reflected in Figure 4 for plots above the chaining. This difference has occurred without this higher transect portion having undergone the more intensive treatment used on the chained area. Within these, a significant increase was found for the warm season species Bouteloua gracilis (Kunth) Lagasca y Segura, as well as highly significant increases for cool season Oryzopsis hymenoides Roemer \& Schultes and Sitanion hystrix (Scribner) J. G. Smith. These species represent the bulk of the more

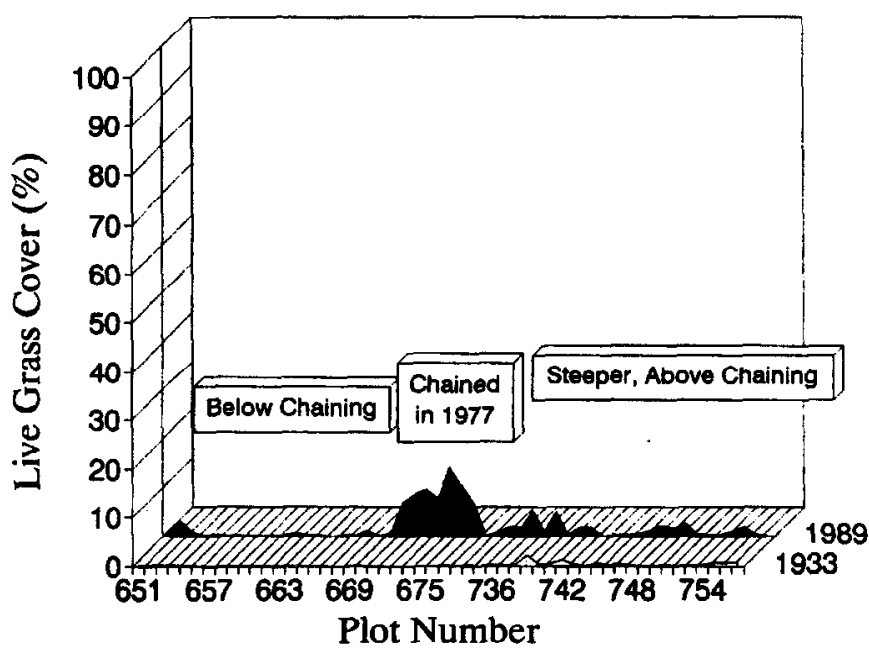

Fig. 4. Spatial variation in total live plant cover by perennial grasses, for all plots, from northeast, lowest elevation (left) to southwest, highest elevation (right) for all plots along the pinyon-juniper woodland transect, Pine Valley, Ut., 1933 and 1989. 
than threefold increase in cover among grass species for the unseeded area (Table 1).

On the other hand, plots below the chaining (i.e., numbers 651-669) are, at most, a few hundred meters from a graveled road, and are less steep, with consequently easier access for a variety of uses. These plots had the smallest increase in grass cover (Fig. 4).

In both 1933 and 1989, the greater plant species richness of the pinyon-juniper zone is striking, relative to that reported in Yorks et al. (1992) for the other vegetation types along the ovcrall transcet. The total number of species in the pinyon-juniper type is twice that found in the sagebrush type, which is in contrast to the more commonly expressed depauperate expectations for such woodlands (West et al. 1979).

However, as was the case in all the other local areas restudied in 1989, overall species richness in the pinyon-juniper type has changed little with time, although a substantial apparent difference may be seen among individual species (Table 1). Introduced species, in particular Bromus tectorum L. and Halogeton glomeratus (M.Bieberstein) C.A.Meyer, that were not found to be present in 1933 appear in 1989, although in quite small quantities.

With regard to tree density, Figure 5 indicates that there has been a tripling in the number of trees present, which is highly significant. These data are consistent with a shift in tree cover from juniper to pinyon, because the latter species has a narrower crown diameter at maturity, with no concomitant increase in overall tree cover. There has also been a significant decline in the number of dead trees, which continue to appear as isolated individuals or in small patches. Seedling numbers did not differ significantly. Average shrub density (Fig. 6) indicates that the increased shrub cover in 1989 (Fig. 1) is also combined with greater shrub numbers. Dead shrubs have declined, while seedling numbers have increased, both highly significantly (Fig. 6).

Stubbendieck et al. (1982)'s definitions were employed to derive the cool-season to warm-season grass ratio (i.e., those with $\mathrm{C}_{3}$ to $\mathrm{C}_{4}$ photosynthetic pathways), which can provide an indicator of long-term climate variations. This was little changed, from 1.5 in 1933 to 1.3 in 1989 along the transect.

In another measure of community dynamics, the average successional index of Tausch et al. (1981), a quantitative measure of tree dominance, applied to all the plots has shifted from 0.9 in 1933 to 0.6 in 1989 , when all understory cover species are considered. If the moss

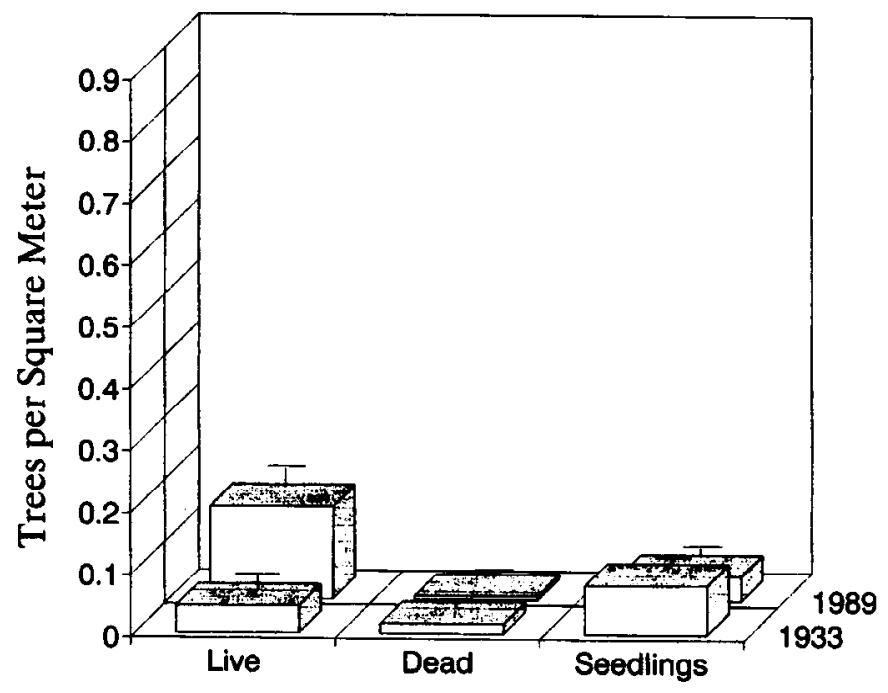

Fig. 5. Average tree density, for unseeded plots, in the pinyon-juniper woodlands in Pine Valley, Ut., 1933 and 1989. and lichen portion of the understory cover is discounted, because these species may not have becn fully surveyed on all plots in 1933, the successional index remains 0.9 for 1933 , and is 0.7 for 1989 , still confirming a full class shift away from tree dominance for 1989.

\section{Discussion}

A key finding of the 1989 resurvey is evidence of a relative shift in cover towards shrubs and perennial grasses, not just where there had been chaining and seeding, but also along the entire transect path. This is an unexpected trend in a previously tree-dominated community that is still primarily grazed by livestock, at least in the absence of fire or other forms of extreme intermediate treatment (West 1984, 1988). The retention of a quite limited presence of annual, introduced species is notable also, given the problems with their increased density elsewhere in the western U.S. (West 1988).

Our data are insufficient to deduce directly even general patterns of causation for these observed differences. Nevertheless, the similarity in climate both for several years before and during the 2 active study years should minimize influences from short-term vegetation response to precipitation (Olson et al. 1985). Additionally, Sims (1988) argued that, over time, longer-term climate (i.e., temperature and precipitation) changes may be expected to shift the relative percentage of cool- to warm-season grasses, and to do so predictably. Since this measurable parameter was not found to have changed, this provides some explicit evidence that other observed differences were probably not climatically induced.

While the total number of species is more or less unchanged, the clear indication from examination of dominance/diversity (Fig. 2) is that more species are playing an appreciable role, and so could serve as a set of buffers against specialized environmental pressures. This should result in a heightened responsiveness, and thus allow overall growth to occur over a wider range of conditions (Westman 1990). Accordingly, this community appears to have become more "robust".

Our results stand in contrast to previous studies (e.g., West 1984) which assert that if an area with a pinyon-juniper overstory was heavily grazed in the past, and then simply left with livestock grazing as its only treatment, the tree cover continues to close in, to the detriment of the understory plants, even when livestock grazing intensity has been substantially reduced. Our results agree favorably with the recent observations of Beymer and Klopatek (1992) of greater amounts of

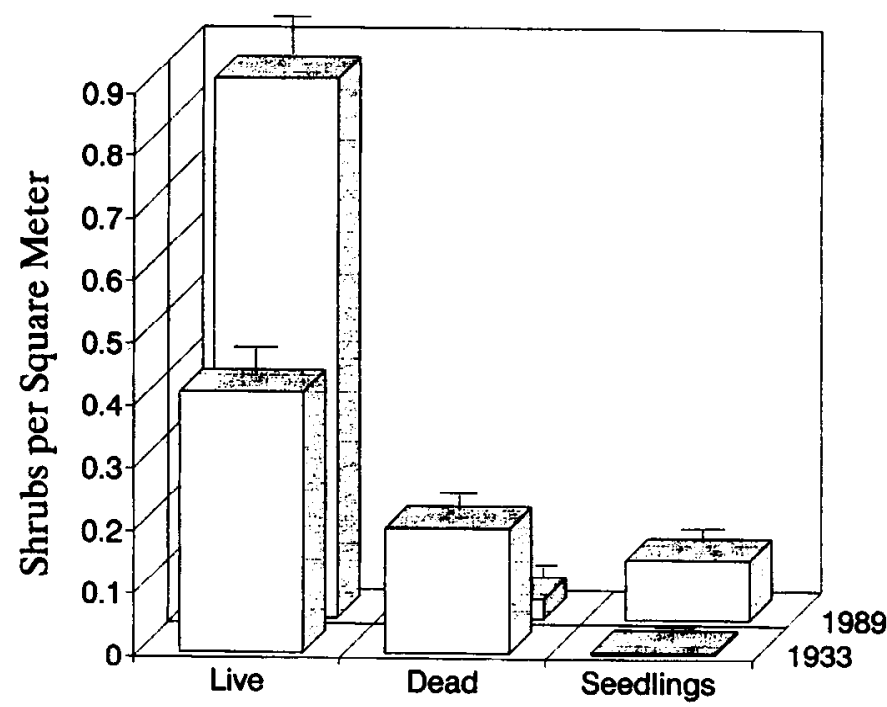

Fig. 6. Average shrub density, for unseeded plots, in the pinyon-juniper woodlands in Pine Valley, Ut., 1933 and 1989. 
perennial grasses in the least disturbed segments of a chronosequence in northern Arizona.

Examination of tree cover (Fig. 3) indicates that the portion of the transect where understory increases are most notable outside the chained area (in Fig. 4) is also the portion where tree cover is actually most substantial. However, the wooded portions of the transect where understory increases were the most apparent were also those sections where extensive rock outcroppings could play a role in keeping the tree cover open, since sunlight and water might more easily reach smaller species. That competitive advantage may be augmented by the increased slope gradient, which also allows the possibility of greater light penetration below the rather short trees. Alternatively, these same steep and rocky conditions are likely to reduce both livestock and direct human use.

It should be noted that other pinyon-juniper woodlands in Pine Valley, which are closer to more heavily used roads, and therefore to the increase in dispersed human activity that is related to vehicular access, do appear to the qualitative eye to have the much more depauperate understory that range managers and other observers generally associate with livestock grazing in pinyon-juniper areas. In this context, those plots on the transect line nearest to even a lightly-used road (i.e., numbers 651 to 670 in Fig. 4) had the least increase in their understory from 1933 to 1989.

Since this road also marks the closest area to open water, and follows some of the most level contours within this range site, it delineates the portion of the unseeded area that would be expected to receive the most grazing attention from livestock within this very large, internally unfenced allotment (Andrew 1988). It is important to note, however, that vegetation impacts resulting more directly from human activity (e.g., off-road vehicles, camping, or wood gathering) are especially difficult to separate from those caused by domestic animals, because of the degree to which these land utilization patterns tend to overlap.

Grazing records indicated that there may have been quite low rates of utilization by sheep during a 10-year-intermediate period within the pinyon-juniper woodlands. This possible rest period could have augmented local recovery.

The overall threefold increase in perennial grasses here, while yet small in absolute terms, is still large enough as a percentage of the 1933 presence to confirm that the similar central conclusion of Yorks et al. (1992) for shrublands also applies within pinyon-juniper woodlands. When changes among the grasses are combined with those for other understory growth forms, the differences which were observed in Pine Valley can only be held as strong evidence that in at least one publicly owned area, improvement in condition has indeed occurred, and that this is concurrent with changes in livestock management (i.e., reductions in pressure in both length of seasons of use and in absolute numbers of animals, but not in their elimination) which followed the Taylor Grazing Act of 1934. This result cannot be extrapolated without extreme caution, however, especially to areas where shorter times for recovery, wildfire, or less conservative human or animal use, in any form, has occurred.

For the future, this particular study area provides points of special additional interest, e.g., competition for limited forage resources, and the role of wildlife in vegetation status. Elk (Cervus canadensis) populations, which share the dietary preferences of domestic livestock, have dramatically increased in number on adjoining land, and are not inhibited from movement onto the study area by existing fences. The current upward trend in condition may face additional pressure from this source.

\section{Literature Cited}

Andrew, M. H. 1988. Grazing impact in relation to livestock watering points. Trends in Res. in Ecol. and Evol. 3:336-339.
Anon. 1988. Utah list of scientific and common plant names. USDA-SCS, Salt Lake City, Ut.

Balda, R. P., and N. Masters. 1980. Avian communities in the pinyon-juniper woodland: a descriptive analysis, p. 146-169. In: R. M. DeGraff and N. G. Tilghman (eds.), Management of western forests and grasslands for nongame birds, USDA Forest Service Gen. Tech. Rep. INT-86. Intermountain Forest and Range Expt. Sta., Ogden, Ut.

Beymer, R. M., and J. M. Klopatek. 1992. Effects of grazing on cryptogamic crusts in pinyon-juniper woodlands in Grand Canyon National Park. Amer. Midl. Nat. 127:139-148.

Box, T. 1990. Rangelands, p. 101-120. In: R. N. Sampson and D. Hair (eds.), Natural resources for the 21 st century. Island Press, Washington, D.C.

Clary, W. P., and R. C. Holmgren. 1982. Desert Experimental Range: establishment and research contribution. Rangelands 6:261-264.

Cottam, W. P. 1961. Our renewable wild lands--a challenge. University of Utah Press, Salt Lake City, Ut.

Evans, R. A. 1988. Management of pinyon-juniper woodlands. USDA Forest Service Gen. Tech. Rep. INT-249. Intermountain Res. Sta., Ogden, Ut.

Goodrich, S. 1986. Vascular plants of the Desert Experimental Range, Millard County, Utah. USDA Forest Service Gen. Tech. Rep. INT-209. Intermountain Res. Sta., Ogden, Ut..

Koniak S., and R. L. Everett. 1982. Seed reserves in soils of successional stages of pinyon woodlands. Amer. Midl. Nat. 108:295-303.

Laycock, W. A. 1991. Stable states and thresholds of range conditions on North American rangelands. J. Range Manage. 44:427-433.

Lewis, A. E. 1984. Biostatistics. Van Nostrand, N.Y.

Murdoch, J. R., and S. L. Welsh. 1971. Land use in Wah Wah and Pine Valleys, Western Utah. Brigham Young Univ. Biol. Ser. 12(4), Provo, Ut.

Olson, K. C., R. S. White, and B. W. Sindelar. 1985. Response of vegetation of the Northern Great Plains to precipitation amount and grazing intensity. J. Range Manage. 38:357-361.

Sims, P. L. 1988. Grasslands, p. 265-286. In: M. G. Barbour and W. D. Billings (eds.), North American terrestrial vegetation. Cambridge University Press, Cambridge, England.

Sneva, F., and C. M. Britton. 1983. Adjusting and forecasting herbage yields in the intermountain big sagebrush region of the steppe province. Oregon State Univ. Sta. Bull. 659, Corvallis, Ore.

Stewart, G., and S. S. Hutchings. 1936. The point-observation-plot (squarefoot density) method of vegetation survey. J. Amer. Soc. Agron. 28:714-722.

Stewart, G., W. P. Cottam, and S. S. Hutchings. 1940. Influence of unrestricted grazing on northern salt desert plant associations in Western Utah. J. Ag. Res. 60:289-316.

Stubbendieck, J., S. L. Hatch, and K. J. Kjar. 1982. North American range plants, 2nd ed. Univ. Neb. Press, Lincoln, Nebr.

Tausch, R. J., and N. E. West. 1989. Differential establishment of pinyon and juniper following fire. Amer. Midl. Nat. 119:174-184.

Tausch, R. J., N. E. West, and A. A. Nabi. 1981. Tree age and dominance patterns in Great Basin pinyon-juniper woodlands. J. Range Manage. 34:259264.

Wald, J., and D. Alberswerth. 1989. Our ailing public rangelands: still ailing. Nat. Wildl. Fed. and Natur. Resources Defense Counc., Washington, D.C.

West, N. E. 1984. Successional patterns and productivity potentials of pinyonjuniper ecosystems, p. 1301-1332. In: Nat. Res. Counc./Nat. Acad. Sci., Developing strategies for rangeland management. Westview Press, Boulder, Colo.

West, N. E. 1988. Intermountain deserts, shrub steppes, and woodlands, p. 209-230. In: M. G. Barbour and W. D. Billings (eds.), North American terrestrial vegetation. Cambridge University Press, Cambridge, England.

West N. E., R. J. Tausch, K. H. Rea, and P. T. Tueller. 1979. Phytogeographic variation within juniper-pinyon woodlands of the Great Basin, p. 119-136. In: Intermountain biogeography: a symposium (coordinators $\mathrm{K}$. T. Harper and J. L. Reveal), Great Basin Naturalist Memoirs No. 2. Brigham Young Univ. Press, Provo, Ut..

West, N. E., and T. J. Hatton. 1990. Relative influence of observer error and plot randomization on detection of vegetation change. Coenoses 5:45-49.

Westman, W. A. 1990. Managing for biodiversity. BioScience 40:26-33.

Wheeler, J. L., L. H. Prasetyo, and H. I. Davies. 1989. Viewpoint: do your digits betray you or does rounding raise your reputation? J. Range Manage. $42: 420$

Yorks, T. P., N. E. West, and K. M. Capels. 1992. Vegetation differences in desert shrublands of Western Utah's Pine Valley between 1933 and 1989. J. Range Manage. 45:569-578. 